\title{
PERSEPSI DAN PREFERENSI PENGUNJUNG UNTUK ARAHAN PENATAAN TAMAN ABHIRAMA
}

\author{
Mazidah Inayati ${ }^{1)}$, Jelita Citrawati Jihan ${ }^{2)}$ \\ 1) 2)Perencanaan Wilayah dan Kota, Fakultas Teknik Sipil dan Perencanaan \\ Universitas PGRI Adi Buana Surabaya
}

\begin{abstract}
Abstrak
Dinas Lingkungan Hidup dan Kebersihan (DLHK) Kabupaten Sidoarjo membangun beberapa taman baru, salah satunya adalah Taman Abhirama yang dibangun pada tahun 2015. Taman Abhirama mempunyai elemen-elemen yang dapat memberikan rasa kepuasan pengunjung untuk berkunjung maka perlu adanya penelitian dan belum ada penelitian mengenai arahan Taman Abhirama. Tujuan penelitian ini adalah untuk mengetahui kondisi fasilitas Taman Abhirama, untuk mengetahui persepsi dan preferensi pengunjung terhadap fasilitas, dan untuk melakukan arahan penataan Taman Abhirama berdasarkan persepsi dan preferensi pengunjung. Metode analisis data adalah analisis importance performance analysis dan analisis perancangan Hamid Shirvani. Hasil analisis kondisi fasilitas Taman Abhirama terdapat 6 jenis fasilitas kondisi kurang baik dan 4 jenis fasilitas kondisi baik. Analisis persepsi dan preferensi pengunjung terhadap fasilitas Taman Abhirama menghasilkan 4 kuadran diantaranya kuadran I meliputi fasilitas tempat/alat bermain dan toilet, kuadran II meliputi penanda (papan informasi) dan musholla, kuadran III meliputi bangku taman dan kolam ikan, kuadran IV meliputi tempat parkir, pedestrian, gazebo, lampu taman, dan tempat sampah. Arahan penataan Taman Abhirama berdasarkan persepsi dan preferensi pengunjung adalah arahan penataan tata guna lahan, arahan penataan sirkulasi dan parkir, arahan penataan ruang terbuka, arahan penataan jalur pejalan kaki, dan arahan penataan penandaan.
\end{abstract}

Kata kunci: Pengunjung, Taman Abhirama, Persepsi dan Preferensi

\begin{abstract}
Sidoarjo district's environmental and hygiene services built several new parks, one of them is Abhirama Park which was built in 2015. Abhirama Park has elements that can give visitors a sense of satisfaction to visit, so there is a need for research and there is no research on the direction of Abhirama Park. The purpose of this study was to determine the condition of Abhirama Park facilities, to find out the visitors perceptions and preferences of the facility, and to conduct the direction of the Abhirama Park arrangement based on visitors perceptions and preferences. The method of data analysis is the analysis of importance performance analysis and analysis of the design of Hamid Shirvani. The results of the analysis of Abhirama Park facility conditions contained 6 types of facilities in poor condition and 4 types of facilities in good condition. Analysis of visistor perceptions and preferences for Abhirama Park facilities resulted in 4 qudrants including quadrant I including playground and toilet facilities, quadrant II including makers (information boards) and musholla, quadrant III covering park benches and fish pond, quadrant IV covering parking lots, pedestrian, gazebo, garden lights, and trash bins. Abhirama Park arrangement of directions based on visistors perceptions and preferences are arrangement of direction for land use, arrangement of direction for circulation and parking, arrangement of direction for open space, arrangement of direction for pedestrian ways, and arrangement of direction for signage.
\end{abstract}

Keywords: Visitors, Abhirama Park, Perceptions and Preferences. 


\section{PENDAHULUAN}

Taman kota adalah ruang di dalam kota yang ditata untuk menciptakan keindahan, kenyamanan, keamanan, dan kesehatan bagi penggunanya (Iswara, 2017). Taman kota dapat difungsikan sebagai paru-paru kota, pengendali iklim mikro, konservasi tanah dan air, habitat berbagai flora dan fauna (Pramono, 2010). Selain itu, sebagai tempat rekreasi, hiburan masyarakat, dan tempat bermain anak yang tentunya menyehatkan serta murah untuk semua kalangan dan strata sosial masyarakat (DEWIYANTI, 2007).

Pemerintah Kabupaten Sidoarjo membangun ruang terbuka hijau di beberapa wilayah. Ruang terbuka hijau yang dimaksud tidak hanya untuk penghijauan saja tetapi dapat digunakan untuk acara keluarga atau anak-anak seperti taman. Pembangunan taman di beberapa lokasi dapat menciptakan kondisi kota yang indah, sejuk, dan nyaman serta menunjukkan citra kota yang baik, serta menjadi ikon lingkungan di Kabupaten Sidoarjo. Dinas Lingkungan Hidup dan Kebersihan (DLHK) Kabupaten Sidoarjo membangun beberapa taman baru diantaranya Taman Abhirama, Taman Tanjung Puri, Taman Dwarakerta, dan lain-lain (Rifa'i, n.d.).

Taman Abhirama merupakan salah satu Taman Kota baru Kabupaten Sidoarjo. Taman Abhirama dibangun tahun 2015 dengan luas sebesar $6790 \mathrm{~m}^{2}$. Lokasi Taman Abhirama berada bersebelahan dengan kompleks Perumahan Pondok Jati Kabupaten Sidoarjo. Taman ini mempunyai beberapa elemen-elemen yang terkait didalamnya, antara lain penanda (papan informasi), tempat parkir, pedestrian, gazebo, toilet, kolam ikan, bangku taman, lampu taman, musholla, tempat sampah, dan tempat/alat bermain. Adanya elemen-elemen di Taman Abhirama dapat memberikan rasa kepuasan pengunjung untuk berkunjung dengan begitu perlu perhatian mengenai kondisi fisik. Dilihat dari kondisi fisik Taman Abhirama saat ini dapat memberikan rasa menarik untuk pengunjung yang datang tetapi ada beberapa kondisi fasilitas kurang baik karena mengalami kerusakan, maka berdasarkan temuan kondisi fisik di lapangan perlu adanya penelitian "Persepsi dan Preferensi Pengunjung Untuk Arahan Penataan Taman Abhirama".

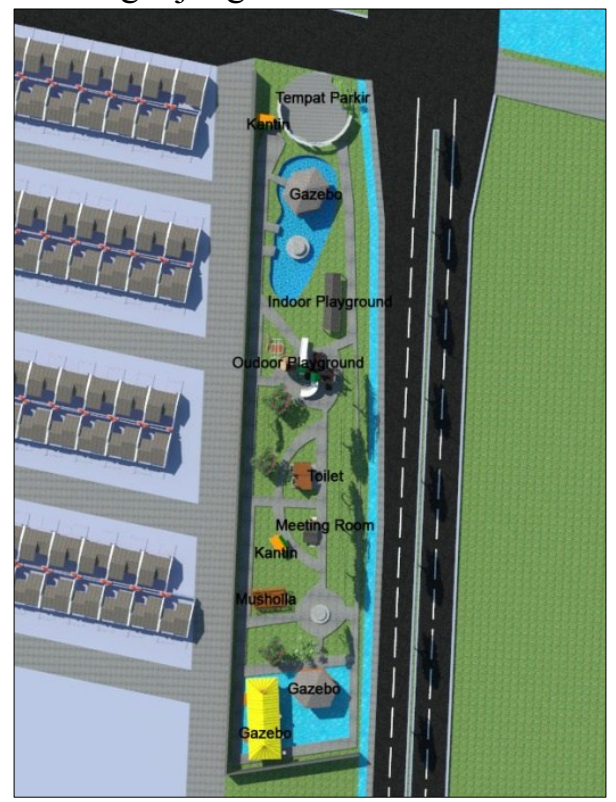

Gambar 1 Peta Tapak Wilayah Studi

\section{METODOLOGI}

Metodologi adalah mengkaji mengenai metode-metode yang digunakan dalam penelitian ini, dapat dilihat pada gambar 2 . 
Latar Belakang

1. Timbulnya adanya kepuasan pengunjung adalah apabila komponen-komponen fasilitas penunjang Taman Abhirama

2. Ada beberapa kondisi fasilitas kurang baik

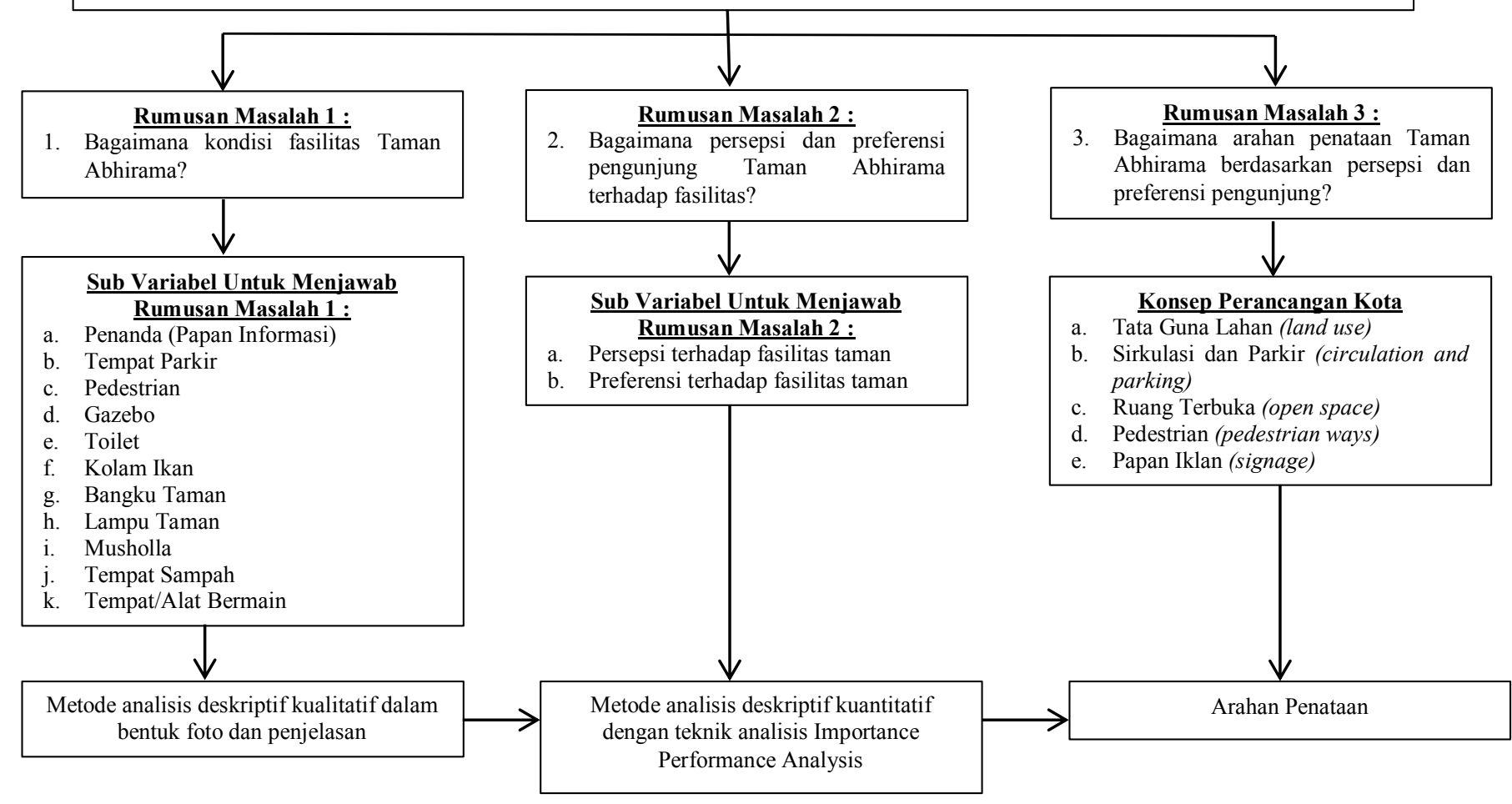

Gambar 2 Kerangka Pikir Penelitian

Berdasarkan gambar 2 menjelaskan bahwa penelitian ini mempunyai 3 rumusan masalah. Rumusan masalah 1 terbagi 11 variabel antara lain penanda (papan informasi), tempat parkir, pedestrian, gazebo, toilet, kolam ikan, bangku taman, lampu taman, musholla, tempat sampah, dan tempat/alat bermain. Metode analisis menggunakan analisis deskriptif kualitatif dalam bentuk foto dan penjelasan. Rumusan masalah 2 terbagi 2 variabel antara lain persepsi terhadap fasilitas taman dan preferensi terhadap fasilitas taman. Metode analisis menggunakan analisis deskriptif kuantitatif dengan teknik analisis importance performance analysis. Rumusan masalah 3 menggunakan konsep perancangan kota Hamid Shirvani terbagi 5 variabel antara lain tata guna lahan, sirkulasi dan parkir, ruang terbuka, pedestrian, dan papan iklan menghasilkan arahan penataan.

\section{HASIL DAN PEMBAHASAN}

Hasil dan pembahasan ini menjelaskan mengenai analisis kondisi fasilitas Taman Abhirama, analisis persepsi dan preferensi pengunjung Taman Abhirama terhadap fasilitas, dan analisis arahan penataan Taman Abhirama berdasarkan persepsi dan preferensi pengunjung.

a. Analisis Kondisi Fasilitas Taman Abhirama

Analisis ini menjelaskan mengenai kondisi eksisting fasilitas Taman Abhirama. Ada penelitian yang sama mengenai kondisi fasilitas taman antara lain arena bermain anak, tempat parkir, dan jalur pedestrian (Pambudi, 2015). Adapun penelitian lain yang sama mengenai kondisi fasilitas taman antara lain tempat sampah dan lampu taman (Alda, 2015). Taman Abhirama mempunyai beberapa fasilitas, dapat dilihat pada tabel 1 . 
Tabel 1 Kondisi Eksisting Fasilitas Taman Abhirama Tahun 2018

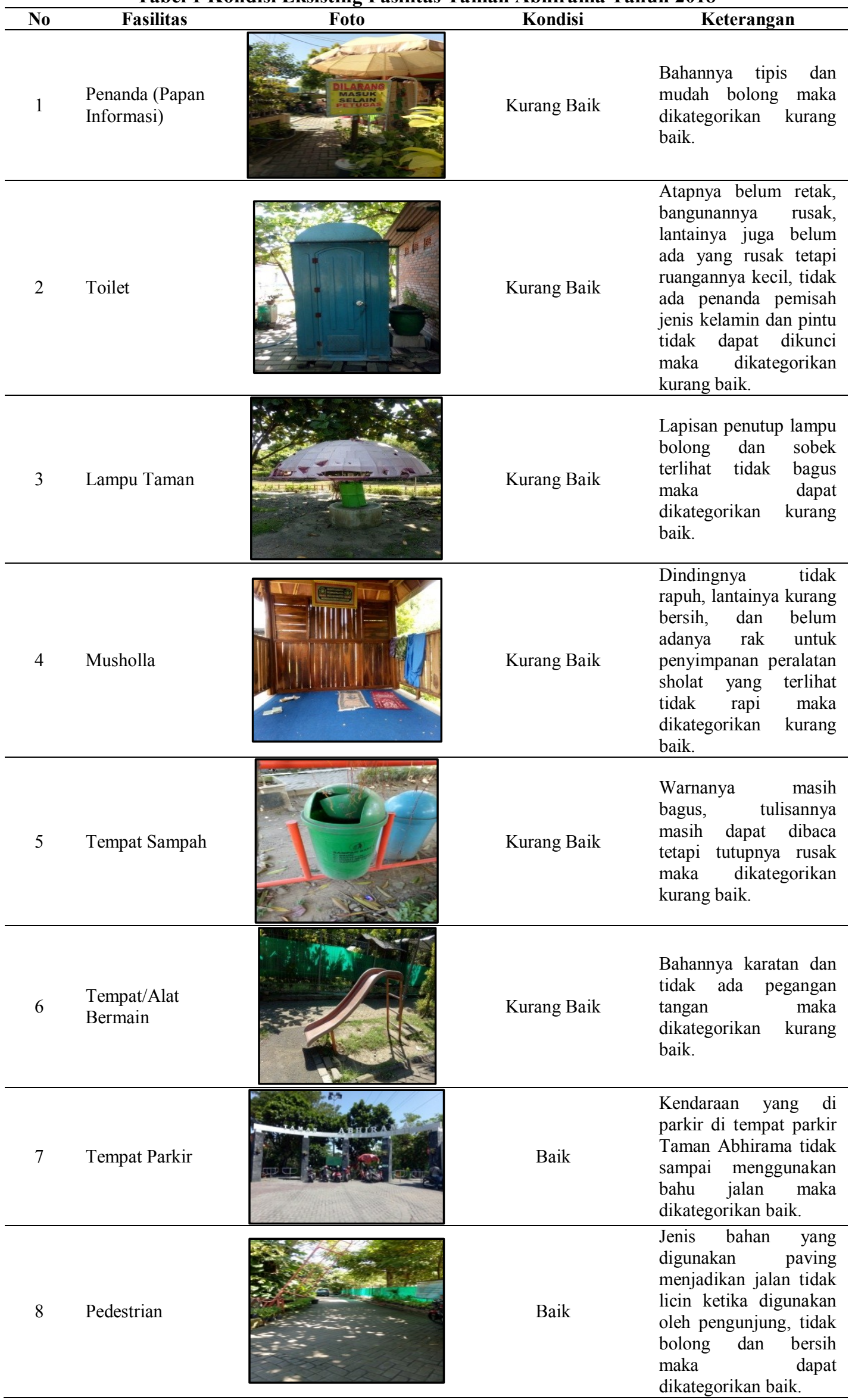




\begin{tabular}{|c|c|c|c|c|}
\hline No & Fasilitas & Foto & Kondisi & Keterangan \\
\hline 9 & Gazebo & & Baik & $\begin{array}{l}\text { Atapnya tidak ada yang } \\
\text { bolong, bangunannya } \\
\text { juga tidak ada yang } \\
\text { rapuh, dan warnanya } \\
\text { juga masih terlihat } \\
\text { bagus maka } \\
\text { dikategorikan baik. }\end{array}$ \\
\hline 10 & Kolam Ikan & & Baik & $\begin{array}{l}\text { Airnya bening, airnya } \\
\text { penuh, masih banyak } \\
\text { ikan didalamnya dan } \\
\text { dindingnya tidak bocor } \\
\text { maka dapat } \\
\text { dikategorikan baik. }\end{array}$ \\
\hline 11 & Bangku Taman & & Baik & $\begin{array}{l}\text { Bahannya tidak retak, } \\
\text { dan warnanya masih } \\
\text { bagus maka dapat } \\
\text { dikategorikan baik. }\end{array}$ \\
\hline
\end{tabular}

Sumber: Hasil Analisis, 2018

Berdasarkan tabel 1 menjelaskan bahwa kondisi fasilitas Taman Abhirama tahun 2018 terbagi 2 yaitu kondisi kurang baik dan kondisi baik. Kondisi kurang baik antara lain fasilitas penanda (papan informasi), toilet, lampu taman, musholla, tempat sampah, dan tempat/alat bermain. Kondisi baik antara lain tempat parkir, pedestrian, gazebo, kolam ikan, dan bangku taman.

b. Analisis Persepsi dan Preferensi Pengunjung

Analisis ini menjelaskan mengenai persepsi dan preferensi pengunjung terhadap fasilitas Taman Abhirama. Metode analisis menggunakan analisis deskriptif kuantitatif dengan teknik analisis importance performance analysis (IPA). Analisis importance performance analysis terdiri dari 2 komponen yaitu analisis kuadran dan analisis kesenjangan (gap). Setelah analisis kuadran dan analisis kesenjangan, kemudian nilai-nilai tersebut diplotkan ke dalam diagram kartesius. Sebelum analisis persepsi dan preferensi pengunjung menggunakan importance performance analysis (IPA), melakukan penilaian bobot dengan menggunakan skala likert. Adapun penelitian yang sama menggunakan analisis persepsi dan preferensi dengan teknik analisis importance performance analysis (Sugesti, 2014) .

1) Penilaian Bobot Pada Persepsi dan Preferensi Pengunjung

Penilaian bobot pada persepsi dan preferensi pengunjung adalah memasukkan data-data kuesioner pengunjung dengan menggunakan skala likert. Penilaian bobot persepsi terbagi 5 yaitu sangat baik adalah 5, baik adalah 4, cukup adalah 3, kurang adalah 2, dan sangat kurang adalah 1. Penilaian bobot preferensi terbagi 5 yaitu sangat penting adalah 5, penting adalah 4, biasa adalah 3, tidak penting adalah 2, dan sangat tidak penting adalah 1 .

Tabel 2 Perhitungan Bobot Persepsi Pengunjung Terhadap Fasilitas Taman Abhirama Tahun 2018

\begin{tabular}{|c|c|c|c|c|c|c|c|c|c|c|c|}
\hline No & Fasilitas & SB & SB $\times$ Bobot & B & B $\times$ Bobot & $\mathbf{C}$ & C $\times$ Bobot & $\mathbf{K}$ & K $\times$ Bobot & SK & SK $\times$ Bobot \\
\hline 1 & $\begin{array}{l}\text { Penanda (Papan } \\
\text { Informasi) }\end{array}$ & 6 & 30 & 31 & 124 & 20 & 60 & 10 & 20 & 0 & 0 \\
\hline 2 & Tempat Parkir & 5 & 25 & 40 & 160 & 18 & 54 & 4 & 8 & 0 & 0 \\
\hline 3 & Pedestrian & 4 & 20 & 53 & 212 & 9 & 27 & 1 & 2 & 0 & 0 \\
\hline 4 & Gazebo & 10 & 50 & 29 & 116 & 21 & 63 & 7 & 14 & 0 & 0 \\
\hline 5 & Toilet & 1 & 5 & 13 & 52 & 13 & 39 & 39 & 78 & 1 & 1 \\
\hline 6 & Kolam Ikan & 3 & 15 & 21 & 84 & 36 & 108 & 7 & 14 & 0 & 0 \\
\hline 7 & Bangku Taman & 3 & 15 & 18 & 72 & 35 & 105 & 11 & 22 & 0 & 0 \\
\hline 8 & Lampu Taman & 3 & 15 & 38 & 152 & 16 & 48 & 10 & 20 & 0 & 0 \\
\hline 9 & Musholla & 4 & 20 & 26 & 104 & 31 & 93 & 6 & 12 & 0 & 0 \\
\hline 10 & Tempat Sampah & 2 & 10 & 28 & 112 & 34 & 102 & 3 & 6 & 0 & 0 \\
\hline 11 & Tempat/Alat Bermain & 4 & 20 & 37 & 148 & 4 & 12 & 22 & 44 & 0 & 0 \\
\hline & Total & 45 & 225 & 334 & 1336 & 237 & 711 & 120 & 240 & 1 & 1 \\
\hline
\end{tabular}




\section{Sumber: Hasil Analisis, 2018}

Berdasarkan tabel 2 menjelaskan bahwa perhitungan bobot persepsi pengunjung terhadap fasilitas Taman Abhirama tahun 2018. Perhitungan bobot fasilitas penanda (papan informasi) terbagi 5 antara lain sangat baik berjumlah 30, baik berjumlah 124, cukup berjumlah 60, kurang berjumlah 20 , dan sangat kurang berjumlah 0 . Perhitungan bobot fasilitas tempat parkir terbagi 5 antara lain sangat baik berjumlah 25 , baik berjumlah 160 , cukup berjumlah 54, kurang berjumlah 8 , dan sangat kurang berjumlah 0 . Perhitungan bobot fasilitas pedestrian terbagi 5 antara lain sangat baik berjumlah 20, baik berjumlah 212, cukup berjumlah 27, kurang berjumlah 2, dan sangat kurang berjumlah 0 . Perhitungan bobot fasilitas gazebo terbagi 5 antara lain sangat baik berjumlah 50 , baik berjumlah 116, cukup berjumlah 63 , kurang berjumlah 14 , dan sangat kurang berjumlah 0 . Perhitungan bobot fasilitas toilet terbagi 5 antara lain sangat baik berjumlah 5 , baik berjumlah 52 , cukup berjumlah 39 , kurang berjumlah 78 , dan sangat kurang berjumlah 1. Perhitungan bobot fasilitas kolam ikan terbagi 5 antara lain sangat baik berjumlah 15, baik berjumlah 84 , cukup berjumlah 108, kurang berjumlah 14 , dan sangat kurang berjumlah 0 . Perhitungan bobot fasilitas bangku taman terbagi 5 antara lain sangat baik berjumlah 15, baik berjumlah 72 , cukup berjumlah 105, kurang berjumlah 22 , dan sangat kurang berjumlah 0 . Perhitungan bobot fasilitas lampu taman terbagi 5 antara lain sangat baik berjumlah 15 , baik berjumlah 152 , cukup berjumlah 48 , kurang berjumlah 20 , dan sangat kurang berjumlah 0 . Perhitungan bobot fasilitas musholla terbagi 5 antara lain sangat baik berjumlah 20, baik berjumlah 104, cukup berjumlah 93, kurang berjumlah 12, dan sangat kurang berjumlah 0 . Perhitungan bobot fasilitas tempat sampah terbagi 5 antara lain sangat baik berjumlah 10 , baik berjumlah 112 , cukup berjumlah 102 , kurang berjumlah 6 , dan sangat kurang berjumlah 0 . Perhitungan bobot fasilitas tempat/alat bermain terbagi 5 antara lain sangat baik berjumlah 20 , baik berjumlah 148 , cukup berjumlah 12 , kurang berjumlah 44 , dan sangat kurang berjumlah 0 .

Tabel 3 Perhitungan Bobot Preferensi Pengunjung Terhadap Fasilitas Taman Abhirama Tahun 2018

\begin{tabular}{|c|c|c|c|c|c|c|c|c|c|c|c|}
\hline No & Fasilitas & SP & SP $\times$ Bobot & $\mathbf{P}$ & P $\times$ Bobot & B & B $\times$ Bobot & $\mathbf{T P}$ & TP $\times$ Bobot & STP & STP $\times$ Bobot \\
\hline 1 & $\begin{array}{l}\text { Penanda (Papan } \\
\text { Informasi) }\end{array}$ & 49 & 245 & 16 & 64 & 2 & 6 & 0 & 0 & 0 & 0 \\
\hline 2 & Tempat Parkir & 23 & 115 & 39 & 156 & 5 & 15 & 0 & 0 & 0 & 0 \\
\hline 3 & Pedestrian & 25 & 125 & 37 & 148 & 5 & 15 & 0 & 0 & 0 & 0 \\
\hline 4 & Gazebo & 27 & 135 & 34 & 136 & 6 & 18 & 0 & 0 & 0 & 0 \\
\hline 5 & Toilet & 48 & 240 & 18 & 72 & 1 & 3 & 0 & 0 & 0 & 0 \\
\hline 6 & Kolam Ikan & 2 & 10 & 49 & 196 & 15 & 45 & 1 & 2 & 0 & 0 \\
\hline 7 & Bangku Taman & 33 & 165 & 29 & 116 & 4 & 12 & 1 & 2 & 0 & 0 \\
\hline 8 & Lampu Taman & 28 & 140 & 32 & 128 & 6 & 18 & 1 & 2 & 0 & 0 \\
\hline 9 & Musholla & 47 & 235 & 18 & 72 & 2 & 6 & 0 & 0 & 0 & 0 \\
\hline 10 & Tempat Sampah & 26 & 130 & 39 & 156 & 2 & 6 & 0 & 0 & 0 & 0 \\
\hline 11 & $\begin{array}{l}\text { Tempat/Alat } \\
\text { Bermain }\end{array}$ & 47 & 235 & 18 & 72 & 2 & 6 & 0 & 0 & 0 & 0 \\
\hline & Total & 355 & 1775 & 329 & 1316 & 50 & 150 & 3 & 6 & $\mathbf{0}$ & $\mathbf{0}$ \\
\hline
\end{tabular}

Berdasarkan tabel 3 menjelaskan bahwa perhitungan bobot preferensi pengunjung terhadap fasilitas Taman Abhirama tahun 2018. Perhitungan bobot fasilitas penanda (papan informasi) terbagi 5 antara lain sangat penting berjumlah 245, penting berjumlah 64, biasa berjumlah 6 , tidak penting berjumlah 0 , dan sangat tidak penting berjumlah 0 . Perhitungan bobot fasilitas tempat parkir terbagi 5 antara lain sangat penting berjumlah 115, penting berjumlah 156, biasa berjumlah 15 , tidak penting berjumlah 0 , dan sangat tidak penting berjumlah 0 . Perhitungan bobot fasilitas pedestrian terbagi 5 antara lain sangat penting berjumlah 125 , penting berjumlah 148 , biasa berjumlah 15 , tidak penting berjumlah 0 , dan sangat tidak penting berjumlah 0 . Perhitungan bobot fasilitas gazebo terbagi 5 antara lain sangat penting berjumlah 135 , penting berjumlah 136 , biasa berjumlah 18 , tidak penting berjumlah 0 , dan sangat tidak penting berjumlah 0 . Perhitungan bobot fasilitas toilet terbagi 5 antara lain sangat penting berjumlah 240 , penting berjumlah 72 , biasa berjumlah 3 , tidak penting berjumlah 
0 , dan sangat tidak penting berjumlah 0 . Perhitungan bobot fasilitas kolam ikan terbagi 5 antara lain sangat penting berjumlah 10, penting berjumlah 196, biasa berjumlah 45 , tidak penting berjumlah 2, dan sangat tidak penting berjumlah 0 . Perhitungan bobot fasilitas bangku taman terbagi 5 antara lain sangat penting berjumlah 165, penting berjumlah 116, biasa berjumlah 12 , tidak penting berjumlah 2, dan sangat tidak penting berjumlah 0. Perhitungan bobot fasilitas lampu taman terbagi 5 antara lain sangat penting berjumlah 140, penting berjumlah 128, biasa berjumlah 18 , tidak penting berjumlah 2 , dan sangat tidak penting berjumlah 0 . Perhitungan bobot fasilitas musholla terbagi 5 antara lain sangat penting berjumlah 235, penting berjumlah 72 , biasa berjumlah 6 , tidak penting berjumlah 0 , dan sangat tidak penting berjumlah 0 . Perhitungan bobot fasilitas tempat sampah terbagi 5 antara lain sangat penting berjumlah 130, penting berjumlah 156 , biasa berjumlah 6 , tidak penting berjumlah 0 , dan sangat tidak penting berjumlah 0 . Perhitungan bobot fasilitas tempat/alat bermain terbagi 5 antara lain sangat penting berjumlah 235 , penting berjumlah 72 , biasa berjumlah 6 , tidak penting berjumlah 0 , dan sangat tidak penting berjumlah 0 .

2) Analisis Kuadran

Analisis kuadran ini dengan menghitung nilai rata-rata bobot tingkat kinerja/persepsi dan kepentingan/preferensi untuk setiap atribut. Jumlah responden yang digunakan adalah 67. Rumus analisis kuadran, sebagai berikut.

$$
\overline{\mathrm{X}}=\frac{\sum \mathrm{Xi}}{\mathrm{n}} \quad \overline{\mathrm{Y}}=\frac{\sum \mathrm{Yi}}{\mathrm{n}}
$$

Keterangan :

$\overline{\mathrm{X}}=$ Nilai rata-rata bobot tingkat penilaian kinerja atribut ke-i

$\bar{Y}=$ Nilai rata-rata bobot tingkat penilaian kepentingan atribut ke-i

$\mathrm{n}=$ Jumlah responden

Tabel 4 Analisis Kuadran Tahun 2018

\begin{tabular}{cllcccc}
\hline $\mathbf{N o}$ & \multicolumn{1}{c}{ Atribut } & $\mathbf{n}$ & $\sum \mathbf{X i}$ & $\overline{\mathbf{X}}$ & $\mathbf{Y i}$ & $\overline{\mathbf{Y}}$ \\
\hline 1 & $\begin{array}{l}\text { Penanda (Papan } \\
\text { Informasi) }\end{array}$ & 67 & 234 & 3,49 & 315 & 4,70 \\
\hline 2 & Tempat Parkir & 67 & 247 & 3,69 & 286 & 4,27 \\
\hline 3 & Pedestrian & 67 & 261 & 3,89 & 288 & 4,30 \\
\hline 4 & Gazebo & 67 & 243 & 3,63 & 289 & 4,31 \\
\hline 5 & Toilet & 67 & 175 & 2,61 & 315 & 4,70 \\
\hline 6 & Kolam Ikan & 67 & 221 & 3,30 & 253 & 3,78 \\
\hline 7 & Bangku Taman & 67 & 214 & 3,19 & 295 & 4,40 \\
\hline 8 & Lampu Taman & 67 & 235 & 3,51 & 288 & 4,30 \\
\hline 9 & Musholla & 67 & 229 & 3,42 & 313 & 4,67 \\
\hline 10 & Tempat Sampah & 67 & 230 & 3.43 & 292 & 4,36 \\
\hline 11 & Tempat/Alat Bermain & 67 & 224 & 3,34 & 313 & 4,67 \\
\hline
\end{tabular}

Sumber: Hasil Analisis, 2018

Berdasarkan tabel 4 menjelaskan bahwa hasil analisis kuadran setiap atribut tahun 2018 diantaranya hasil nilai rata-rata bobot tingkat penilaian kinerja/persepsi dan kepentingan/preferensi untuk atribut penanda (papan informasi) adalah $\bar{X}=3,49$ dan $\bar{Y}=4,70$. Hasil nilai rata-rata bobot tingkat penilaian kinerja/persepsi dan kepentingan/preferensi untuk atribut tempat parkir adalah $\bar{X}=3,69$ dan $\bar{Y}=4,27$. Hasil nilai rata-rata bobot tingkat penilaian kinerja/persepsi dan kepentingan/preferensi untuk atribut pedestrian adalah $\overline{\mathrm{X}}=3,89$ dan $\overline{\mathrm{Y}}=$ 4,30. Hasil nilai rata-rata bobot tingkat penilaian kinerja/persepsi dan kepentingan/preferensi untuk atribut gazebo adalah $\bar{X}=3,63$ dan $\bar{Y}=4,31$. Hasil nilai rata-rata bobot tingkat penilaian kinerja/persepsi dan kepentingan/preferensi untuk atribut toilet adalah $\bar{X}=2,61$ dan $\bar{Y}=4,70$. Hasil nilai rata-rata bobot tingkat penilaian kinerja/persepsi dan kepentingan/preferensi untuk atribut kolam ikan adalah $\bar{X}=3,30$ dan $\bar{Y}=3,78$. Hasil nilai rata-rata bobot tingkat penilaian kinerja/persepsi dan kepentingan/preferensi untuk atribut bangku taman adalah $\bar{X}=3,19$ dan $\bar{Y}=$ 4,40. Hasil nilai rata-rata bobot tingkat penilaian kinerja/persepsi dan kepentingan/preferensi untuk atribut lampu taman adalah $\bar{X}=3,51$ dan $\bar{Y}=4,30$. Hasil nilai rata-rata bobot tingkat penilaian kinerja/persepsi dan kepentingan/preferensi untuk atribut musholla adalah $\overline{\mathrm{X}}=3,42$ 
dan $\bar{Y}=4,67$. Hasil nilai rata-rata bobot tingkat penilaian kinerja/persepsi dan kepentingan/preferensi untuk atribut tempat sampah adalah $\bar{X}=3,43$ dan $\bar{Y}=4,36$. Dan hasil nilai rata-rata bobot tingkat penilaian kinerja/persepsi dan kepentingan/preferensi untuk atribut tempat/alat bermain adalah $\bar{X}=3,34$ dan $\bar{Y}=4,67$.

3) Analisis Kesenjangan (GAP)

Analisis kesenjangan (GAP) ini dengan menghitung rata-rata tingkat kepentingan/preferensi dan kinerja/persepsi untuk keseluruhan atribut dengan rumus:

$$
\overline{\overline{\mathrm{X}}}=\frac{\sum \overline{\mathrm{X}_{1}}}{\mathrm{n}} \quad \overline{\overline{\mathrm{Y}}}=\frac{\sum \overline{\mathrm{Y}_{1}}}{\mathrm{n}}
$$

Keterangan:

$\overline{\bar{X}_{1}}=$ Nilai rata-rata kinerja atribut

$\overline{\bar{Y}} \mathbf{l}=$ Nilai rata-rata kepentingan atribut

$\mathrm{n}=$ Jumlah atribut

Tabel 5 Analisis Kesenjangan (GAP) Tahun 2018

\begin{tabular}{clcc}
\hline No & \multicolumn{1}{c}{ Atribut } & $\overline{\mathbf{X}}$ & $\overline{\mathbf{Y}}$ \\
\hline 1 & Penanda (Papan Informasi) & 3,49 & 4,70 \\
\hline 2 & Tempat Parkir & 3,69 & 4,27 \\
\hline 3 & Pedestrian & 3,89 & 4,30 \\
\hline 4 & Gazebo & 3,63 & 4,31 \\
\hline 5 & Toilet & 2,61 & 4,70 \\
\hline 6 & Kolam Ikan & 3,30 & 3,78 \\
\hline 7 & Bangku Taman & 3,19 & 4,40 \\
\hline 8 & Lampu Taman & 3,51 & 4,30 \\
\hline 9 & Musholla & 3,42 & 4,67 \\
\hline 10 & Tempat Sampah & 3,43 & 4,36 \\
\hline 11 & Tempat/Alat Bermain & 3,34 & 4,67 \\
\hline & $\sum \overline{\mathbf{X}} \mathbf{1}$ dan $\sum \overline{\mathbf{Y}} \mathbf{1}$ & 37,50 & 48,45 \\
\hline & $\overline{\mathbf{X}}$ dan $\overline{\overline{\mathbf{Y}}}$ & 3,41 & 4,40
\end{tabular}

Sumber: Hasil Analisis, 2018

Berdasarkan tabel 5 menjelaskan bahwa hasil perhitungan analisis kesenjangan (gap) pada semua atribut yang digunakan didapatkan nilai $\overline{\bar{X}}$ adalah 3,41 . Sedangkan untuk nilai $\overline{\bar{Y}}$ adalah 4,40 .

4) Diagram Kartesius

Diagram kartesius ini pembagian kuadran menjadi 4 kuadran dengan titik potong sumbu $\mathrm{X}$ dan titik potong sumbu $\mathrm{Y}$ berdasarkan perhitungan nilai rata-rata tingkat kinerja/persepsi dan nilai rata-rata tingkat kepentingan/preferensi yang sudah dijelaskan diatas (Kaligis, 2014).

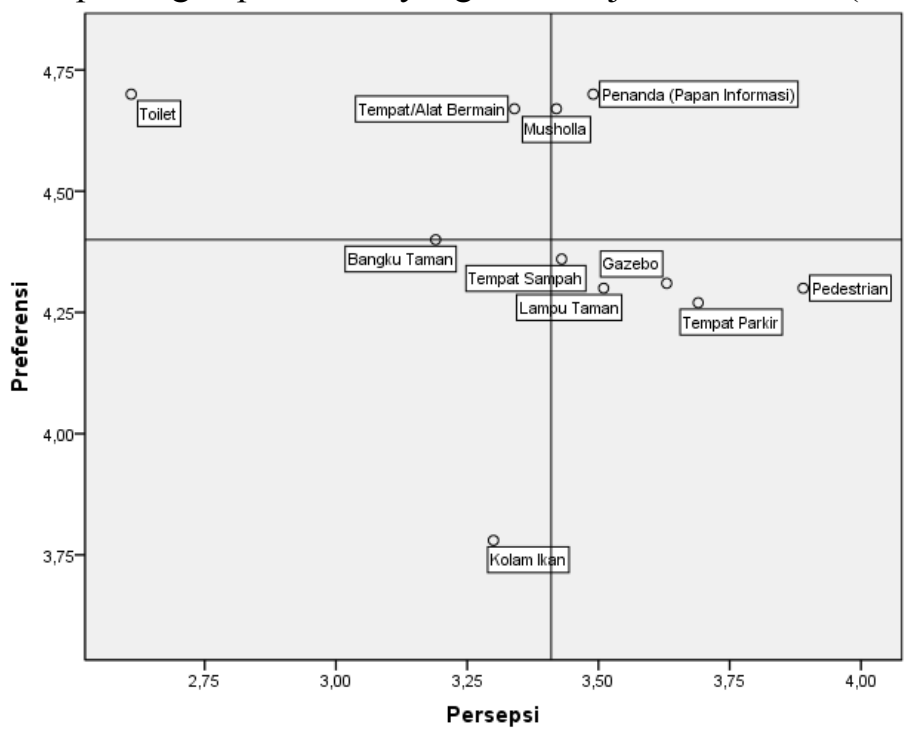

Gambar 3 Analisis Diagram Kartesius Tahun 2018 
Berdasarkan gambar 3 menjelaskan bahwa analisis diagram kartesius yang termasuk dalam kuadran I antara lain tempat/alat bermain dan toilet karena menurut pengunjung fasilitas tersebut dianggap tidak penting tetapi pelayananannya belum sesuai harapan. Kuadran II antara lain penanda(papan informasi) dan musholla karena menurut pengunjung fasilitas tersebut dianggap penting tetapi pelayanannya sudah sesuai harapan. Kuadran III antara lain bangku taman dan kolam ikan karena menurut pengunjung fasilitas tersebut dianggap kurang penting dan pelayanannya tidak terlalu istimewa. Kuadran IV antara lain tempat parkir, pedestrian, gazebo, lampu taman, dan tempat sampah karena menurut pengunjung fasilitas tersebut dianggap kurang penting dan pelayanannya berlebihan.

c. Analisis Arahan Penataan Kawasan

Analisis ini menjelaskan mengenai arahan penataan Taman Abhirama berdasarkan persepsi dan preferensi pengunjung. Analisis arahan penataan ini menggunakan konsep perancangan kota menurut Hamid Shirvani (1985). Konsep perancangan kota yang digunakan dalam penelitian ini adalah tata guna lahan, sirkulasi dan parkir, ruang terbuka, jalur pejalan kaki, dan penandaan. Penelitian arahan penataan taman menggunakan konsep perancangan kota yang sama dengan penelitian ini adalah penelitian penataan Taman Koa Dadaha Tasikmalaya, konsep perancangan untuk penataan taman yang digunakan adalah arahan tata guna lahan, arahan sirkulasi dan parkir, arahan jalur pejalan kaki, arahan aktivitas pendukung, dan arahan penandaan pada Taman Kota Dadaha (Yakin, 2016). Adapun penelitian lain yang sama mengenai taman yang analisis menggunakan konsep perancangan kota menurut Hamid Shirvani, komponen yang digunakan dalam penelitiannya adalah ruang terbuka, tata bangunan, aktivitas pendukung, dan penandaan (Gunarto, 2014).

1) Arahan Penataan Tata Guna Lahan

Berdasarkan kondisi eksisting tata guna lahan Taman Abhirama adalah tempat parkir, kantin, gazebo, indoor playground, outdoor playground, toilet, meeting room, dan musholla. Arahan penataan tata guna lahan Taman Abhirama adalah tempat parkir, kantin, kolam ikan, gazebo, permainan, toilet, meeting room, dan musholla.

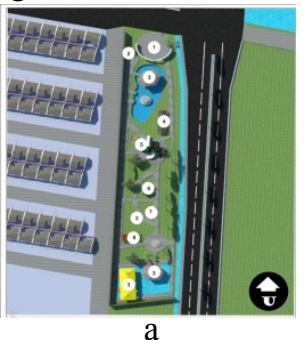

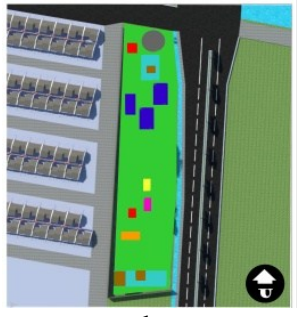

b

2) Arahan Penataan Sirkulasi dan Parkir

Gambar a) Kondisi Eksisting; b) Arahan Penataan Tata Guna Lahan

Arahan penataan ini adalah melakukan arahan penataan sirkulasi dan parkir Taman Abhirama.

a) Berdasarkan kondisi eksisting sirkulasi Taman Abhirama adalah 2 arah dan tidak beraturan. Arahan penataan sirkulasi Taman Abhirama adalah menjadi 1 arah.

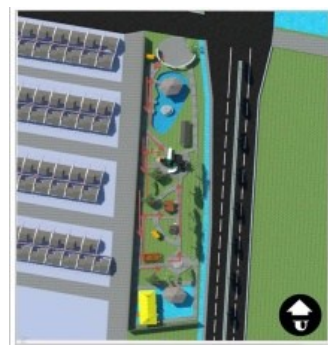

a

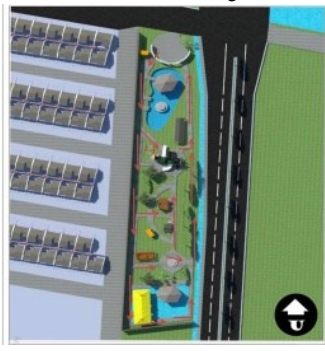

b

Gambar a) Kondisi Eksisting; b) Arahan Penataan Sirkulasi

b) Berdasarkan kondisi eksisting parkir Taman Abhirama adalah kendaraan yang di parkir Taman Abhirama tidak sampai menggunakan bahu jalan. Arahan penataan parkir Taman Abhirama adalah kendaraan sepeda motor jenis parkir menggunakan jenis parkir paralel, sedangkan kendaraan mobil menggunakan jenis parkir serong. 


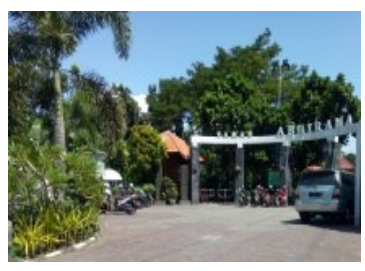

a

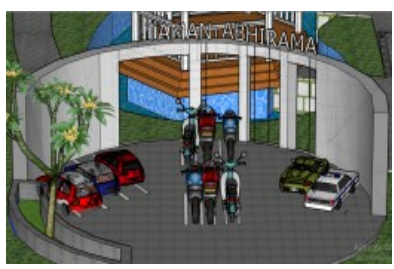

b

3) Arahan Penataan Ruang Terbuka

Gambar a) Kondisi Eksisting; b) Arahan Penataan Parkir

Arahan penataan ruang terbuka adalah melakukan arahan penataan toilet, arahan penataan tempat/alat bermain, arahan penataan gazebo, arahan penataan kolam ikan, arahan penataan bangku taman, arahan penataan lampu taman, arahan penataan musholla, dan arahan penataan tempat sampah.

a) Arahan Penataan Toilet

Berdasarkan kondisi eksisting toilet Taman Abhirama adalah toilet Taman Abhirama terbagi 2 bangunan, untuk bangunan ke 2 ruangannya kecil, tidak ada penanda pemisah jenis kelamin dan kunci pintu tidak berfungsi. Arahan penataan toilet Taman Abhirama adalah dibangun ulang dijadikan 1 bangunan dan ada penanda pemisah jenis kelamin (pria dan wanita).

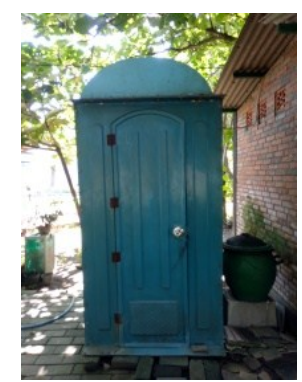

a

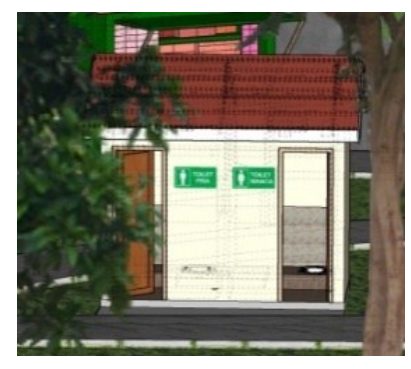

b

Gambar a) Kondisi Eksisting; b) Arahan Penataan Toilet

b) Arahan Penataan Tempat/Alat Bermain

Berdasarkan kondisi eksisting tempat/alat bermain Taman Abhirama adalah bahannya tidak karatan. Arahan penataan tempat/alat bermain Taman Abhirama adalah membuat matras dari rumput dibawah setiap fasilitas tempat/alat bermain.

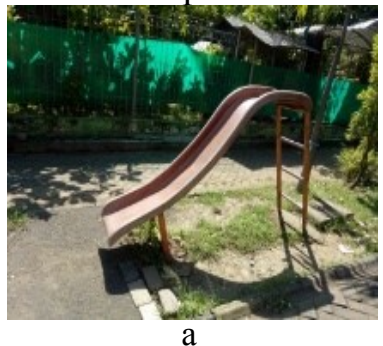

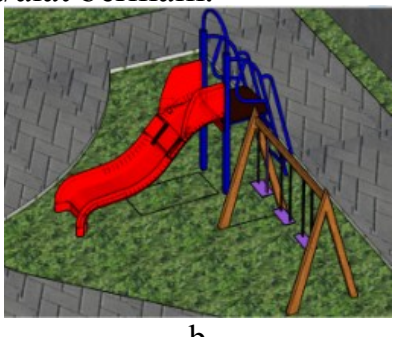

b

Gambar a) Kondisi Eksisting; b) Arahan Penataan Tempat/Alat Bermain

c) Arahan Penataan Gazebo

Berdasarkan kondisi eksisting gazebo Taman Abhirama adalah atapnya tidak ada yang bolong, bangunannya tidak ada yang rapuh, dan warnanya juga masih terlihat bagus. Arahan penataan gazebo Taman Abhirama adalah adanya fasilitas pengisian daya berupa stop kontak. 


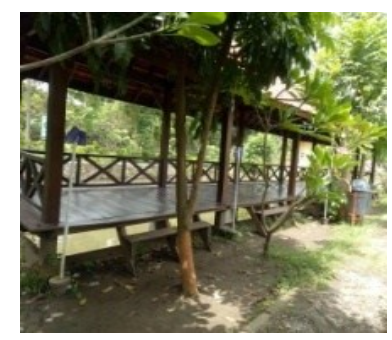

a

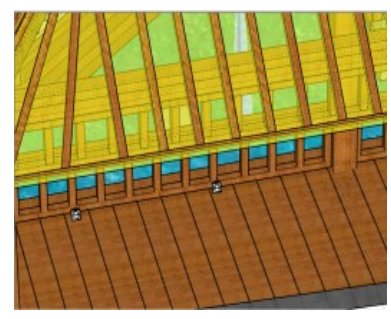

b

d) Arahan Penataan Kc Gambar a) Kondisi Eksisting; b) Arahan Penataan Gazebo

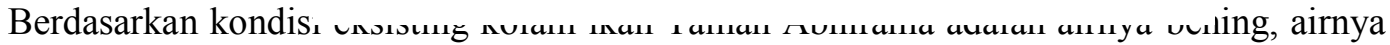
penuh, masih banyak ikan didalamnya dan dindingnya tidak bocor. Arahan penataan kolam ikan Taman Abhirama adalah adanya air mancur bergoyang.

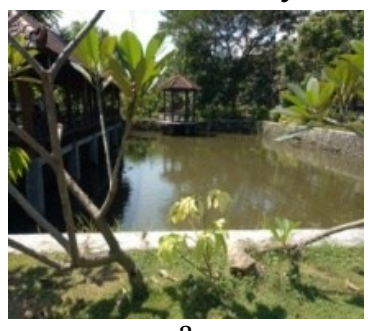

a

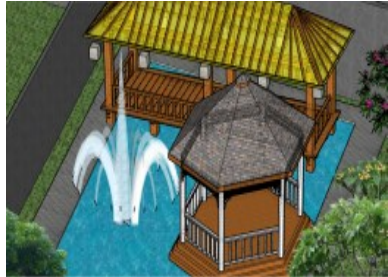

b

Gambar a) Kondisi Eksisting; b) Arahan Penataan Gazebo

e) Arahan Penataan Bangku Taman

Berdasarkan kondisi eksisting bangku Taman Abhirama adalah bahannya tidak retak, tidak karatan, dan warnanya masih bagus. Arahan penataan bangku Taman Abhirama adalah penggantian bangku yang ada sandaran.

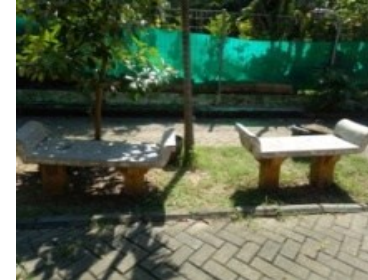

a

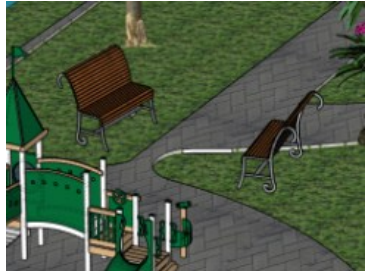

Gambar a) Kondisi Eksisting; b) Arahan Penataan Bangku Taman

f) Arahan Penataan Lampu Taman

Berdasarkan kondisi eksisting lampu Taman Abhirama adalah penutup lampu taman bolong dan sobek terlihat tidak bagus. Arahan penataan lampu Taman Abhirama adalah perbaikan lampu taman.

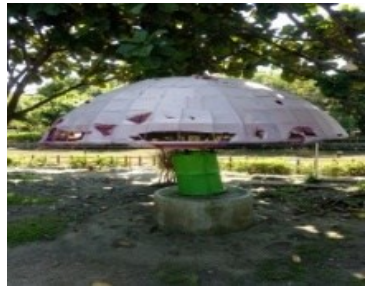

a

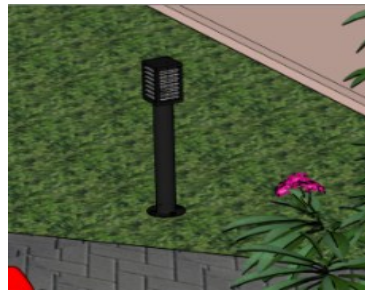

$\mathrm{b}$

g) Arahan Penataan Musholla

Gambar a) Kondisi Eksisting; b) Arahan Penataan Lampu Taman

Berdasarkan kondisi eksisting musholla Taman Abhirama adalah atapnya tidak bolong dan dindingnya tidak rapuh hanya saja tempatnya kurang rapi karena peralatan sholat berserakan. Arahan penataan musholla Taman Abhirama adalah adanya rak kecil. 


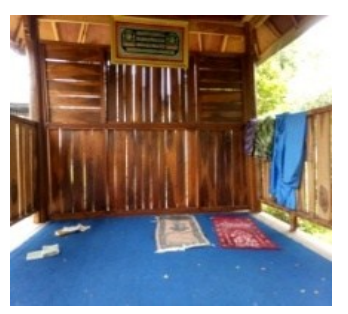

a

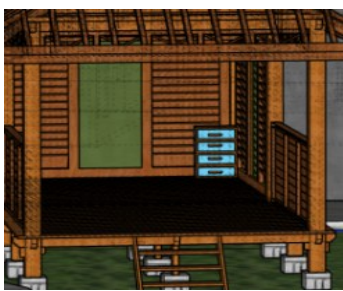

b

Gambar a) Kondisi Eksisting; b) Arahan Penataan Musholla

h) Arahan Penataan Tempat Sampah

Berdasarkan kondisi eksisting tempat sampah Taman Abhirama adalah warnanya masih bagus dan tulisan masih dapat dibaca tetapi penutup tempat sampah tidak berfungsi. Arahan penataan tempat sampah Taman Abhirama adalah perbaikan tempat sampah.

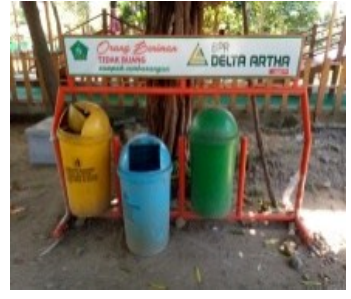

a

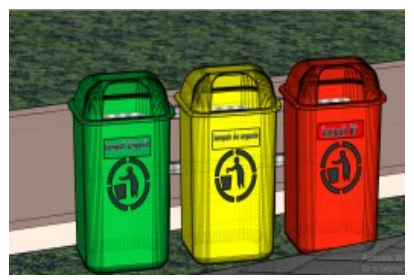

b

Gambar a) Kondisi Eksisting; b) Arahan Penataan Tempat Sampah

4) Arahan Penataan Jalur Pejalan Kaki

Berdasarkan kondisi eksisting jalur pejalan kaki Taman Abhirama adalah pedestrian Taman Abhirama belum adanya jalan yang bolong dan sudah ada jalan untuk refleksi kaki. Arahan penataan jalur pejalan kaki Taman Abhirama adalah adanya jalan untuk kursi roda.

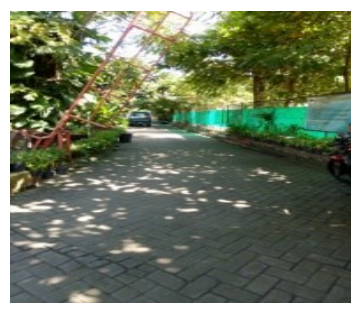

a

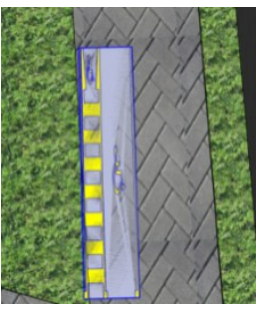

b

Gambar a) Kondisi Eksisting; b) Arahan Penataan Jalur Pejalan Kaki

5) Arahan Penataan Penandaan

Berdasarkan kondisi eksisting penandaan Taman Abhirama adalah penandaan Taman Abhirama terdapat 1 jenis papan informasi yang bahannya tipis dan mudah bolong. Arahan penataan penandaan Taman Abhirama adalah perbaikan 1 unit penandaan papan informasi, penambahan papan petunjuk arah fasilitas Taman Abhirama, dan penambahan papan petunjuk keluar Taman Abhirama.

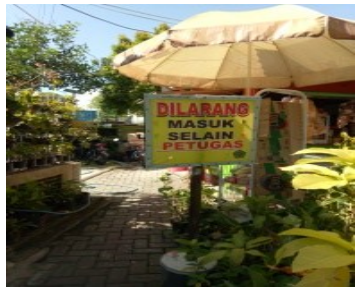

a

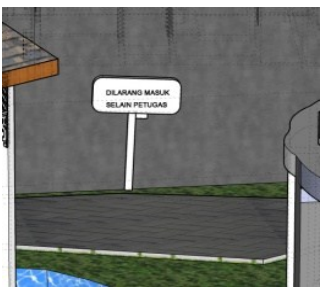

b 


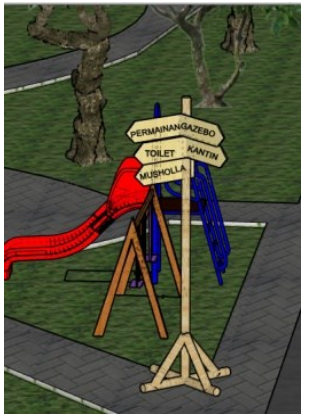

$\mathrm{c}$

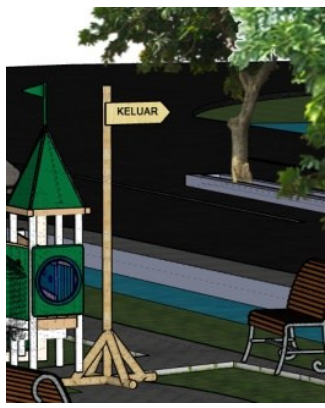

d

Gambar a) Kondisi Eksisting Papan Informasi; b) Arahan Penataan Papan Informasi; c) Arahan Penantaan Penambahan Papan Petunjuk Fasilitas Taman Abhirama; d) Arahan Penataan Penambahan Papan Petunjuk Keluar Taman Abhirama

\section{KESIMPULAN}

Berdasarkan hasil dan pembahasan dapat disimpulkan bahwa:

a. Kondisi fasilitas Taman Abhirama terdapat 6 jenis fasilitas dalam kondisi kurang baik diantaranya penanda (papan informasi), toilet, lampu taman, musholla, tempat sampah, dan tempat/alat bermain. Sedangkan jenis fasilitas yang dalam kondisi baik diantaranya tempat parkir, pedestrian, gazebo, kolam ikan, dan bangku taman.

b. Hasil analisis tingkat kepuasan pengunjung Taman Abhirama terhadap fasilitas terbagi 4 kuadran yaitu kuadran I merupakan menurut pengunjung fasilitas dianggap penting, tetapi pelayanan kondisi eksistingnya belum sesuai harapan meliputi fasilitas/alat bermain dan toilet. Kuadran II merupakan menurut pengunjung fasilitas dianggap penting, tetapi pelayanan kondisi eksistingnya belum sesuai harapan meliputi penanda (papan informasi) dan musholla. Kuadran III merupakan menurut pengunjung fasilitas dianggap kurang penting dan pelayanan kondisi eksistingnya tidak terlalu istimewa meliputi bangku taman dan kolam ikan. Kuadran IV merupakan menurut pengunjung fasilitas dianggap kurang penting dan pelayanan kondisi eksistingnya berlebihan meliputi tempat parkir, pedestrian, gazebo, lampu taman, dan tempat sampah.

c. Arahan penataan kawasan Taman Abhirama berdasarkan tingkat kepuasan pengunjung menggunakan konsep Hamid Shirvani yang terbagi 5 elemen yaitu tata guna lahan, sirkulasi dan parkir, ruang terbuka, pejalan kaki, dan penandaan. Arahan penataan tata guna lahan Taman Abhirama adalah tempat parkir, kantin, kolam ikan, gazebo, permainan, toilet, meeting room, dan musholla. Arahan penataan sirkulasi Taman Abhirama adalah menjadi 1 arah dan arahan penataan parkir Taman Abhirama adalah kendaraan sepeda motor menggunakan jenis parkir paralel, sedangkan kendaraan mobil menggunakan jenis parkir serong. Arahan penataan ruang terbuka Taman Abhirama adalah penataan fasilitas Taman Abhirama meliputi toilet, tempat/alat bermain, gazebo, kolam ikan, bangku taman, lampu taman, musholla, tempat sampah. Arahan penataan pejalan kaki Taman Abhirama adalah menyediakan jalan untuk kursi roda. Arahan penataan penandaan Taman Abhirama adalah perbaikan 1 unit jenis papan informasi, dan penambahan 2 unit jenis papan petunjuk untuk fasilitas dan keluar.

\section{UCAPAN TERIMA KASIH}

Ucapan terima kasih penulis untuk dosen pembimbing tercinta Ibu Jelita Citrawati Jihan.,

ST., MT. dan teman-teman prodi teknik perencanaan wilayah dan kota atas segala bantuan, masukan-masukan dan kekompakannya. 


\section{REFERENSI}

Alda, A. F. (2015). Penataan Taman Tirto Agung Sebagai Ruang Publik Di Kecamatan Banyumanik Semarang, 1(4), 171-180.

DEWIYANTI, D. (2007). Vol.7, No. 1. RUANG TERBUKA HIJAU KOTA BANDUNG Suatu Tinjauan Awal Taman Kota Terhadap Konsep Kota Layak Anak, 7(1), 13-26.

Gunarto, A. (2014). PENGEMBANGAN TAMAN PUBLIK KREATIF KOTA PANGKALAN KERINCI SEBAGAI INSTRUMEN PERENCANAAN KOTA KABUPATEN PELALAWAN-RIAU, (2), 1-23.

Iswara, R. (2017). KESESUAIAN FUNGSI TAMAN KOTA DALAM MENDUKUNG KONSEP KOTA LAYAK HUNI DI SURAKARTA, 15, 115-123.

Kaligis, D. (2014). Pengukuran Tingkat Kepuasan Pengunjung Di Objek Wisata Puncak Temboan Desa Rurukan Satu Kota Tomohon.

Pambudi, B. P. (2015). Optimalisasi Pemanfaatan Taman Kota Oleh Masyarakat Kota Bekasi, $3,1-18$.

Pramono, S. (2010). KONSEP PENATAAN LANSEKAP PADA ALUN-ALUN DAN TAMAN-TAMAN KOTA BONDOWOSO, 3, 23-38.

Rifa'i, R. (N.D.). PERAN DINAS KEBERSIHAN DAN PERTAMANAN DALAM PENGELOLAAN RUANG TERBUKA HIJAU (RTH) DI TAMAN ABHIRAMA KABUPATEN SIDOARJO.

Sugesti, C. (2014). Analisis Persepsi Dan Preferensi Pengunjung Taman Bungkul Kota Surabaya, 32-51.

Yakin, S. D. (2016). Penataan Taman Kota Dadaha Tasikmalaya, 218-226. 